\title{
The association between intellectual capital and financial performance in the Islamic banking industry An analysis of the GCC banks
}

A.A. Ousama

Department of Accounting and Information Systems, College of Business and Economics, Qatar University, Doha, Qatar Helmi Hammami

Department of Finance and Accounting, Rennes School of Business, Rennes, France, and

Mustafa Abdulkarim

Department of Accounting and Information Systems, College of Business and Economics, Qatar University, Doha, Qatar

\begin{abstract}
Purpose - The purpose of this study is to empirically investigate the impact of intellectual capital (IC) on the financial performance of Islamic banks operating in the Gulf Cooperation Council (GCC) countries.
\end{abstract}

Design/methodology/approach - The study measures IC by the value added intellectual coefficient model. A regression analysis was used to assess the impact of IC on financial performance. The research sample consisted of Islamic banks operating in the GCC countries during the years 2011, 2012 and 2013. Data originated from the annual reports of Islamic banks.

Findings - The results support the thesis that IC has a positive impact on the financial performance of Islamic banks. Even though the average IC is lower than that reported in other studies, the positive effect on financial performance is obvious. The findings also show that human capital (HC) is higher than capital employed (CE) and structural capital (SC). The study reveals that SC has an insignificant impact on the financial performance of the Islamic banks compared to $\mathrm{CE}$ and $\mathrm{HC}$.

Practical implications - The findings provide empirical evidence that IC affects the Islamic banks' financial performance. It helps Islamic banks in the GCC countries to understand how to use their IC efficiently, especially SC as it is yet to be used efficiently. Also, the findings benefit the relevant authorities (e.g. legislators and central banks) who could use them to emphasise strategic policy reforms whenever required.

Originality/value - The current research adds to the empirical studies in the GCC countries as it views the region as a collective as opposed to individual countries. It also extends the IC and performance measurement

(C) A.A. Ousama, Helmi Hammami and Mustafa Abdulkarim. Published by Emerald Publishing Limited. This article is published under the Creative Commons Attribution (CC BY 4.0) licence. Anyone may reproduce, distribute, translate and create derivative works of this article (for both commercial and non-commercial purposes), subject to full attribution to the original publication and authors. The full terms of this licence may be seen at http://creativecommons.org/licences/by/4.0/legalcode

The project was funded by the Kuwait Foundation for the Advancement of Sciences.
Received 24 May 2016 Revised 7 August 2017 27 April 2018

27 September 2018 Accepted 2 April 2019

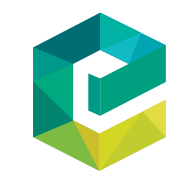

International Journal of Islamic and Middle Eastern Finance and Management Vol. 13 No. 1,2020 pp. $75-93$ Emerald Publishing Limited $1753-839$ 
IMEFM

13,1 literature of Islamic banks in the GCC countries. Moreover, the current study enriches the limited literature on IC in the context of Islamic banking.

Keywords Performance, Impact, GCC countries, Islamic banks, Intellectual capital, VAIC ${ }^{\mathrm{TM}}$ model, CEE, HCE, SCE, ROA, ROE

Paper type Research paper

\section{Introduction}

Today's economy is changing with greater emphasis on intangibles such as intellectual capital (IC). However, financial statements have often failed in reporting IC as a significant proportion of the total value of an organisation. Consequently, firms with high IC might look less valuable than their true worth (Petty and Guthrie, 2000) and thereby risk losing valuable competitive advantage (Lev and Zarowin, 1999; Ruta, 2009; Yang and Lin, 2009).

With the rapid shift to a knowledge economy (Organisation for Economic Co-operation and Development - OECD, 2007), the source of economic value is no longer limited to the production of tangible goods but also to the creation of IC. A shift is occurring away from blue collar jobs that once dominated the economy, to more and more people becoming interested in white collar positions because organisations are increasingly dependent on IC to achieve their financial performance and growth objectives (Chen et al., 2005; Guthrie et al., 2006).

IC is an intangible capital and resource (e.g. knowledge, experience, management philosophy, brands, systems and human resources) that supports the creation of firm value (Brooking, 1996; Edvinsson and Malone, 1997; Stewart, 1997). It is valuable leverage for corporate wealth creation and a profit booster when valued properly (Stewart, 1997; Sullivan, 2000). Several international organisations, such as the World Intellectual Capital Initiative, have been founded with the scope to improve the apprehension of IC and related reporting issues (World Intellectual Capital Initiative - WICI, 2011). The Institute of Management Accountants in a 2010 report entitled "Unrecognised Intangible Assets: Identification, Management and Reporting" called for renewed attention to the growing unrecognised proportion of these intangible assets for financial reporting purposes (Institute of Management Accountants - IMA, 2010). It emphasised that:

These items have grown to become a major source of value to public corporations. They contribute to competitive capacity, and they form a critical aspect of an organisation's sustainability in the future. (Institute of Management Accountants - IMA, 2010: p. 1)

Despite the difficulties of making IC part of the mainstream reporting of assets, awareness of its importance is spreading. Several large and small corporations realised the value of IC as an important component of their sustainability (Marshall et al., 2006; Borkowski et al., 2010). Its importance is, therefore, accentuated by the public interest in sustainable business (Institute of Management Accountants - IMA, 2010; Borkowski et al., 2010).

In a knowledge economy, the efficient management of IC creates a long-term competitive advantage. Strategically, this is very crucial for service industries requiring knowledge and skilled human resources such as those required in the banking sector (Shih et al., 2010; Al-Musali and Ku Ismail, 2014). To achieve their strategic objectives and ensure competitive success, both conventional and Islamic banks are expected to provide high-quality services by investing in the training of their human resources, brand building, systems and processes (Goh, 2005; Ahuja and Ahuja, 2012).

However, despite the growing investment in intangibles in the conventional banking system, intangibles in Islamic banks still represent an under-explored area. Several studies 
investigated the efficient use of IC in the conventional banking system (Goh, 2005; Shih et al., 2010; Ahuja and Ahuja, 2012; Al-Musali and Ku Ismail, 2014) but few focused on Islamic banking (Khalique et al., 2013; Ousama and Fatima, 2015).

Prior literature has evidenced a positive association between IC efficiency and financial performance (Chen et al., 2005; Tan et al., 2007; Mehralian et al., 2012). This is also true for the banking industry (Goh, 2005; Kamath, 2007; Mondal and Ghosh, 2012; Khalique et al., 2013; Ousama and Fatima, 2015). The goals of banks, including Islamic banks, can only be achieved by using all their resources (tangible and intangible/intellectual). Therefore, it is the GCC banks important to examine whether the banking sector is using its IC and is hence able to contribute to the growth of the new economy.

The current study measures IC efficiency by using the value added intellectual coefficient (VAIC ${ }^{\mathrm{TM}}$ ) model in the Islamic banking sector in Gulf Cooperation Council (GCC) countries and investigates the relationship between IC efficiency (i.e. VAIC) and financial performance of Islamic banks. The study adds to the existing literature by capturing the uniqueness of Islamic banking activities such as its Shariah-styled structure that entails skills, processes and products that differ from conventional banking. This uniqueness is a form of IC. Examining the IC in this industry should add to the existing knowledge on the relationship between IC and banking performance. Secondly, the findings help GCC banks self-assess their level of resource efficiency and improve performance. Further, it constitutes an additional layer of scrutiny of the health of Islamic banks.

The remainder of the paper is organised as follows. Section 2 presents an overview of the GCC Islamic banking industry. Section 3 highlights the prior literature and develops the hypotheses. Section 4 details the research method. Section 5 discusses the results, while Section 6 concludes this research.

\section{Islamic banks in the Gulf Cooperation Council countries}

Over the past 10 years, the economies of the GCC countries have seen rapid growth ranging from 5 to 6 per cent of GDP (Al-Kuwari, 2013). Despite the efforts of their respective governments to diversify the economy (Hvidt, 2013), the major contributor to the GDP of the GCC countries is oil and gas (Al-Kuwari, 2013). In 2013, oil and gas revenues represented 49 per cent of the total GDP (World Bank, 2013). After the oil and gas sector, services represent the second most important contribution (Al-Ibrahim, 2004), in which the financial services and the banking industry represent a large portion. Recent years have witnessed the growth in both the size and sophistication of the Gulf banking industry (El-Quqa et al., 2005). A few domestic banks dominate the GCC banking sector (Al-Hassan et al., 2010). Several banks in the GCC countries reported interesting yearly growth after the 2007 financial crisis (El Saadani et al., 2011). According to a Standard \& Poor's report, the total GCC banking assets - including conventional and Islamic - is expected to rise to $\$ 2 \mathrm{tn}$ by the end of 2015 from $\$ 1.7 \mathrm{tn}$ in 2013 (Holmes and Kathpalia, 2014).

Though Islamic financial institutions are spread globally, they are primarily concentrated in the Gulf region. Islamic banks in the GCC countries date back to the 1970 s (Wilson, 2009). Today, the GCC countries are set to be one of the two regional heavyweights and pioneers of the industry along with Malaysia (Wilson, 2009; Holmes and Kathpalia, 2014). They have grown to become a prominent player of financial intermediation in the GCC countries and control on average 24 per cent of the region's banking system assets (AlHassan et al., 2010).

Islamic finance seems to be an attractive opportunity for investors (Pastré and Gecheva, 2008) and has shown a better positioning than conventional banks to absorb external shocks (Hassan and Zaher, 2001) and to generate financial stability (Cihak and Hesse, 2008). From 
IMEFM 13,1

2008 to 2009, the Shariah-compliant assets grew by 29 per cent to reach $\$ 822$ bn (The Economist Group, 2009) with an estimated growth rate of 7 per cent per year through to 2020 (Bain and Company, 2013). With this growth trajectory, the Islamic finance assets are set to reach $\$ 3.4$ tn by the eve of 2020 (Ho and Liau, 2014).

GCC countries' Islamic financial institutions learned a lot from their counterparts in the conventional system and saw their systems and services improve throughout the years. These institutions are getting larger and more global, with more sophisticated techniques and skills in the way they do business (Wilson, 2009). For its future outlook, the Islamic banking industry is set to continue its growth because of the strong economic prospects and governments mega infrastructure projects (Holmes and Kathpalia, 2014).

\section{Literature review and hypotheses}

\subsection{Literature review}

IC literature has increased significantly in the past two decades (Ousama et al., 2011a). Researchers studied several topics covering the definition of IC, its measurement and its reporting, among others (Brooking, 1996; Stewart, 1997; Guthrie et al., 2006; Kamath, 2008; Striukova et al., 2008). Other issues such as determinants of IC disclosure (White $e$ t al., 2007; Whiting and Woodcock, 2011), effect of IC on performance (Bontis et al., 2000), effect of IC information on market value (Ousama et al., 2011b) and usefulness of IC information (Ousama et al., 2011a) have also been examined.

Different accounting models and frameworks for IC measurement have been developed (Guthrie et al., 2007). These frameworks include direct IC methods, market capitalisation methods, firm performance methods and scorecard methods (Sveiby, 2007). The growing number of frameworks stems from the need to reflect the market value of companies in their financial reports (Guthrie et al., 2007). This supports the increasing importance of IC (Marr et al., 2003). IC is a measurement metric in evaluating firm performance using traditional balance sheets and income statements to compare the return of assets between different firms (Guthrie et al., 2007; Bhartesh and Bandyopadhyay, 2005). This approach relies on historical data to compute IC. Iazzolino and Laise (2013) highlighted that over the last three decades, there was more innovated methods to measure IC such as VAIC, economic value added (EVA), human resource accounting, and value chain scoreboard.

Few studies examined IC issues other than the impact of IC efficiency on performance in the GCC countries such as IC disclosure (Abdull Razak et al., 2016), determinants of IC performance (El-bannany, 2012) and IC performance efficiency and corporate governance (Al-Musali and Ku Ismail, 2012a, 2012b). Abdull Razak et al. (2016) examined the IC disclosure in the annual reports of the Saudi banking sector and their IC performance using VAIC. They found that the banks disclosed IC information discursively and human capital (HC) was the highest category. Also, human capital efficiency (HCE) was higher than structural capital efficiency (SCE).

El-bannany (2012) examined the determinants of IC performance of banks in the United Arab Emirates (UAE). He found that investment in information technology systems, barriers to entry, bank risk, bank size, bank age and bank listing age were statistically significant of IC performance. Al-Musali and Ku Ismail (2012a, 2012b) found that corporate governance variables in GCC banks (i.e. board size, number of independent directors, family ownership and domestic strategic institutional ownership), bank-specific characteristics (i.e. bank adherence to Islamic Shariah principles and bank riskiness) and bank industry characteristics (i.e. banking industry concentration and presence of foreign banks) had a significant relationship with IC performance.

Several studies focused on the relationship between IC efficiency and corporate performance of companies and found that IC efficiency is positively related to companies' 
performance (for example Chen et al., 2005 and Wang, 2011 in Taiwan; Cohen and Kaimenakis, 2007 and Maditinos et al., 2011 in Greece; Gan and Saleh, 2008 in Malaysia; Makki and Lodhi, 2008 and Ahmad and Ahmed, 2016 in Pakistan; Clarke et al., 2011 in Australia; Zanjirdar and Kabiribalajadeh, 2011 in Iran; Pal and Soriya, 2012 in India; and Guerrini et al., 2014 in Italy).

With regard to financial institutions, there is a positive relationship between IC efficiency and corporate performance such as Goh (2005) in Malaysia, Yalama and Coskun (2007) in Istanbul, Turkey, Kamath (2007) in India, El-Bannany (2008) in the UK, Joshi et al. (2010) in Australia, Zou and Huan (2011) in China, Abdulsalam et al. (2011) in Kuwait, Al-Musali and Ku Ismail (2014) in Saudi Arabia and Al-Musali and Ku Ismail (2016) in the GCC. Despite the scarcity of studies targeting Islamic financial institutions, i.e. Islamic banks, the existing studies have found similar outputs to conventional banks (Latif et al., 2012 for Pakistan; Ousama and Fatima, 2015 for Malaysia; Setianto and Sukmana, 2016 for Indonesia and Malaysia; and Nawaz and Haniffa, 2017 for Asia, Europe and the Middle East.

Studies that focused on Islamic financial institutions (i.e. banks) mentioned above have found that the banks were able to use their IC resources efficiently with a higher-HCE compared to structural capital (SC) and employed capital efficiencies. These studies confirmed that there is a positive relationship between IC and financial performance (which is similar to the findings of IC and performance of companies). More specifically, Latif $e t$ al. (2012) found that HC had a significant effect on IC and performance. Ousama and Fatima (2015) support the significant impact of IC and its component, i.e. capital employed (CE), SC and HC on the Islamic banks' performance in Malaysia. Setianto and Sukmana (2016) found that IC had a significant impact on banks' performance in Indonesia, but not in Malaysia. This finding is not consistent with the findings of Ousama and Fatima (2015). However, it did support that $\mathrm{HC}$ and $\mathrm{CE}$ influenced banks' performance in both Malaysia and Indonesia. Furthermore, the findings of Ousama and Fatima (2015) and Setianto and Sukmana (2016) were supported by the findings of Nawaz and Haniffa (2017).

The review shows that IC affects the financial performance of banks (both conventional and Islamic). However, this topic of research has not been applied to the GCC countries despite its concentration of Islamic banks. This study addresses this lacuna in the literature.

\subsection{Conceptual framework and development of hypotheses}

According to the resource-based theory, a company is perceived to achieve a comparable sustainable advantage optimising its tangible and intangible assets (Riahi-Belkaoui, 2003). These assets should be valuable, rare, inimitable and non-substitutable (Barney, 1991). The theory views IC as a strategic resource because firms achieve competitive advantage through its efficient use (Zeghal and Maaloul, 2010). While some studies look at IC as a complete set (Youndt et al., 2004), others such as Nawaz (2017) consider IC's components. In this view, Youndt et al. (2004) argue that it might be useful to look at IC as a whole rather than independently focusing on its components. However, the current study agrees with Nawaz (2017) who argues that IC is losing sight of the whole meaning that the literature can treat its components, i.e. $\mathrm{CE}, \mathrm{SC}$ and $\mathrm{HC}$ as a completely independent construct.

The framework for this study as depicted in Figure 1 shows that IC influences corporate performance. The solid line represents the relationship between the IC (i.e. VAIC) and financial performance. The dotted lines represent the relationships between IC components, i.e. capital employed efficiency (CEE), HCE, SCE and financial performance.

3.2.1 Intellectual capital efficiency and performance. The importance of IC has increased and is reflected in creating the value of companies (Holland, 2003). In this regard, value creation in the knowledge-intensive sectors such as the banking industry requires both IC 
IMEFM

13,1

80

and physical capital (Holland, 2010; Chen et al., 2014). Garcia-Meca (2005), Beattie and Thomson (2007), Holland (2010) and Chen et al. (2014) link IC with competitive advantage and a primary source of sustainable competitive advantage in banking (Chen et al., 2014). It is likely that IC relates a firm's competitiveness to firm value. Thus, it is expected that successful companies have a high competitive advantage and higher IC. In other words, the more value IC (VAIC) adds to the Islamic banks in GCC, the higher is its economic performance. Accordingly, the following hypothesis is developed to test the relationship between IC and financial performance:

H1. Islamic banks with greater IC (VAIC) tend to have better financial performance.

3.2.2 Capital employed efficiency and performance. IC should be combined with financial and non-financial assets to create value for firms (Pulic, 1998; De Castro and Sáez, 2008; Murthy and Mouritsen, 2011; Chen et al., 2014). Beltratti and Stulz (2012), Berger and Bouwman (2013) and Chen et al. (2014) suggest that a strong capital base helps banks to enhance the survival likelihood and market share at all times. Some empirical studies found that CEE has a significant positive impact on organisational financial performance (Chen et al., 2005; Chan, 2009a, 2009b). Although, other prior studies in Turkey, Malaysia and Australia found that the CEE was less effective in creating value in the banking sector (Goh, 2005; Joshi et al., 2010; Ozkan et al., 2016). Based on this discussion, the following hypothesis is developed to test the relationship between $\mathrm{CE}$ and financial performance:

H2. Islamic banks with greater $\mathrm{CEE}$ tend to have better financial performance.

3.2.3 Human capital efficiency and performance. HC plays a great role in a firm's value creation (Holland, 2003) and investors incorporate the $\mathrm{HC}$ information into their firm valuation processes. MERITUM (2002: p. 11) defines HC as:

$[\ldots$. the knowledge that the employees take with them when they leave the firm. It includes the knowledge, skills, experiences, and ability of people. Some of this knowledge is unique to the individual; some may be generic. Examples are innovation capacity, creativity, know-how and previous experience, teamwork capacity, employee flexibility, tolerance for ambiguity, motivation, stratification, learning capacity, loyalty, formal training and education.

Lajili and Z'eghal (2005) found a positive and significant association between firm equity market values and HC-related information. The findings of Ozkan et al. (2016) suggest that the IC of the Turkish banking sector is mainly affected by HC. Mondal and Ghosh (2012) reached a similar result in India. Gan and Saleh (2008) and Chu et al. (2011) found that HC plays a major role in enhancing the returns of banks. Al-Musali and Ku Ismail (2014) found that $\mathrm{HC}$ was more efficient in generating value for Islamic banks compared to other IC components. Nawaz (2017) argued that in the case of Islamic banks, HC is important as an

Figure 1.

Theoretical framework

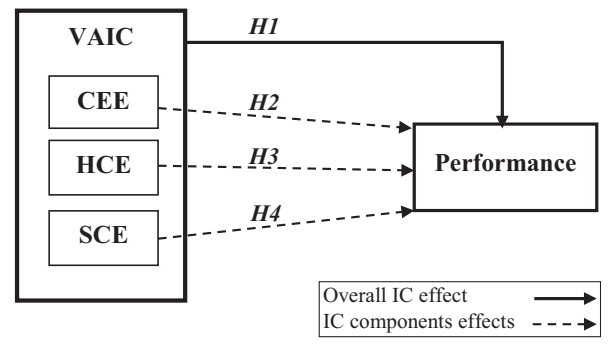


employee having good knowledge of the Shariah (i.e. Islamic laws) will enhance their credibility and reputation in the capital market. Thus, the knowledge embedded in the human CE by the Islamic banks is valuable. Based on this discussion, the following hypothesis is developed to test the relationship between $\mathrm{HC}$ and financial performance:

H3. Islamic banks with greater HCE tend to have better financial performance.

3.2.4 Structural capital efficiency and performance. SC provides an environment which enables an organisation to create and influence knowledge (Nawaz, 2017). An organisation with strong SC encourages an innovative environment (Florin et al., 2003). It is argued that SC has a significant impact on performance (De Brentani and Kleinschmidt, 2004). MERITUM (2002: p. 11) defines SC as:

[...] the knowledge that stays within the firm at the end of the working day. It comprises the organisational routines, producers, systems, culture databases, etc.; examples are organisational flexibility, a documentation service, the existence of a knowledge centre, the general use of information technologies, organisational learning capacity, etc. Some of them may be legally protected and become Intellectual Property Rights, legally owned by the firm under a separate title.

Empirically, Hsu and Wang (2012) found that the SC had a positive effect on the financial performance. On the other hand, Mondal and Ghosh (2012) found that Indian banks' SC was not as important to their profitability. Islamic banks' SC is important as it can provide a good environment for innovation such as new Islamic products, which is expected to enhance the firm's value. Thus, knowledge and management processes along with the philosophy embedded in the structural CE by the Islamic banks are valuable. Based on this discussion, the following hypothesis is developed to test the relationship between SC and financial performance:

H4. Islamic banks with greater SCE tend to have better financial performance.

\section{Research method}

\subsection{Sample and data collection}

The research sample consisted of Islamic banks operating in Bahrain, Qatar, Saudi Arabia and the UAE. Omani full-fledged Islamic banks were excluded from the analysis because of the shortage of data at the time the study was conducted as they started operations in December 2012. A total of 37 Islamic banks were identified, and after excluding banks with missing required data, the study sample comprised 31 Islamic banks as reported in Table I. The research period covered three years from 2011 to 2013. Because of the small number of Islamic banks, the study covered these three years to increase the sample size. This period was selected as it included the most recent data at the time of data collection. In addition, this period was after the global financial crisis to avoid its effects and examine the impact of IC efficiency on financial performance.

\subsection{Variables definition}

4.2.1 Dependent variables. This research uses profitability as a proxy for performance. It represents the dependent variable in the models. It is measured by two financial performance proxies: return on assets $(\mathrm{ROA})=$ operating income/total assets and return on equity $(\mathrm{ROE})=$ net income/shareholders' equity.

4.2.2 Independent variables. IC approached by the VAIC model[1] (Pulic, 1998, 2000) is the independent variable in this research. The model considers the value of a company to 


\begin{tabular}{|c|c|c|}
\hline \multirow{5}{*}{$\begin{array}{l}\text { IMEFM } \\
13,1\end{array}$} & No. & Name of bank \\
\hline & 1 & ABC Islamic Bank \\
\hline & 2 & Al Baraka Bank \\
\hline & 3 & Al Salam Bank \\
\hline & 4 & Bahrain Islamic Bank \\
\hline \multirow{24}{*}{82} & 5 & Bank Al Khair \\
\hline & 6 & Capinnova Investment Bank \\
\hline & $\begin{array}{l}7 \\
8\end{array}$ & City Islamic Investment Bank \\
\hline & $\begin{array}{l}8 \\
9\end{array}$ & $\begin{array}{l}\text { Elaf Bank } \\
\text { Global Banking Corporation }\end{array}$ \\
\hline & 10 & International Investment Bank \\
\hline & 11 & Ithmaar Bank \\
\hline & 12 & liquidity Management Centre \\
\hline & 13 & Seera Investment Bank \\
\hline & 14 & Khaleeji Commercial Bank \\
\hline & 15 & Venture Capital Bank \\
\hline & 16 & Bank Aljazira \\
\hline & 17 & The Islamic Corporation \\
\hline & 18 & Islamic Development Bank \\
\hline & 19 & National commercial Bank \\
\hline & 20 & Ahli United Bank \\
\hline & 21 & Boubyan Bank \\
\hline & 22 & Kuwait International Bank \\
\hline & 23 & Qatar International Islamic Bank \\
\hline & 24 & Qatar Islamic Bank \\
\hline & 25 & Masraf Al Rayan \\
\hline & 26 & Abu Dhabi Islamic Bank \\
\hline & 27 & Ajman Bank \\
\hline & 28 & Al Hilal Bank \\
\hline & 29 & Dubai Islamic Bank \\
\hline Table I. & 30 & Emirates Islamic Bank \\
\hline Sample of the study & 31 & Sharjah Islamic Bank \\
\hline
\end{tabular}

consist of CE (i.e. financial and physical capital) and IC (Pike and Roos, 2004). The latter consists of capital and SC. The VAIC provides information on the value creation efficiency of the physical and IC recourses of a company (Tan et al., 2007). The VAIC model is an analytical process developed to enable stakeholders (e.g. management and shareholders) to effectively control and evaluate the efficiency of the VA by a company's total capital and resources and by each major component of the capital and resources (Firer and Williams, 2003).

The VAIC is measured by the VA efficiency of the IC coefficient for a company. The VA efficiency consists of three efficiency coefficients that include the CEE, the HCE and the structure capital efficiency (SCE). The VAIC is measured by the following formula (Pulic, 1998, 2000; Firer and Williams, 2003): VAIC $=$ CEE + HCE + SCE. The CEE is an indicator of the VA efficiency of $\mathrm{CE}$, which measures as a ratio of the VA of the company and $\mathrm{CE}$. The $\mathrm{CE}$ is the book value of the net assets of the company. CEE is measured by the following formula: $\mathrm{CEE}=\mathrm{VA} / \mathrm{CE}$. The VA is calculated by deducting inputs (i.e. all expenses except personal costs) from outputs (i.e. all income). The following formula is used to measure the VA (Pulic, 1998, 2000; Firer and Williams, 2003): VA = output - input. The HCE is an indicator of the VA efficiency of $\mathrm{HC}$ that measures as a ratio of the VA and total salary and wage of $\mathrm{HC}$ (i.e. personnel cost which is considered an investment). The HCE is measured by the following formula: $\mathrm{HCE}=\mathrm{VA} / \mathrm{HC}$. The SCE is an indicator of VA efficiency of SC, which 
measures the amount needed to invest in SC to generate VA (Pulic, 1998, 2000; Firer and Williams, 2003). The SC is calculated as the difference between VA and $\mathrm{HC}$ (i.e. $\mathrm{SC}=\mathrm{VA}-$ $\mathrm{HC}$ ). The SCE is measured by the following formula: $\mathrm{SCE}=\mathrm{SC} / \mathrm{VA}$.

The control variables include the leverage (i.e. LEVERAGE) which is a ratio of equity and debt used to finance the assets. Leverage is measured based on dividing the total liabilities by total shareholders' equity. Another control variable is the firm size (i.e. SIZE) which is measured by total revenue.

\subsection{Regression models}

Ordinary least squares regression model is used to study the impact of IC (VAIC and its components) on the financial performance. Models $\mathrm{A}$ and $\mathrm{B}$ refer to the financial performance (i.e. ROA and ROE, respectively). Models 1 to 4 test the impact of the VAIC and its three components (i.e. $\mathrm{CEE}, \mathrm{HCE}$ and $\mathrm{SCE}$ ) on financial performance. The models are written as follows:

$$
\begin{aligned}
& \text { Model 1A: } \mathrm{ROA}_{\mathrm{jt}}=\alpha_{\mathrm{jt}}+\beta_{1} \mathrm{VAIC}_{\mathrm{jt}}+\beta_{2} \mathrm{LEVERAGE}_{\mathrm{jt}}+\beta_{3} \mathrm{SIZE}_{\mathrm{jt}}+\varepsilon_{\mathrm{jt}} \\
& \text { Model 1B: } \mathrm{ROE}_{\mathrm{jt}}=\alpha_{\mathrm{jt}}+\beta_{1} \mathrm{VAIC}_{\mathrm{jt}}+\beta_{2} \mathrm{LEVERAGE}_{\mathrm{jt}}+\beta_{3} \mathrm{SIZE}_{\mathrm{jt}}+\varepsilon_{\mathrm{jt}} \\
& \text { Model 2A: } \mathrm{ROA}_{\mathrm{jt}}=\alpha_{\mathrm{jt}}+\beta_{1} \mathrm{CEE}_{\mathrm{jt}}+\beta_{2} \mathrm{LEVERAGE}_{\mathrm{jt}}+\beta_{3} \mathrm{SIZE}_{\mathrm{jt}}+\varepsilon_{\mathrm{jt}} \\
& \text { Model 2B: } \mathrm{ROE}_{\mathrm{jt}}=\alpha_{\mathrm{jt}}+\beta_{1} \mathrm{CEE}_{\mathrm{jt}}+\beta_{2} \mathrm{LEVERAGE}_{\mathrm{jt}}+\beta_{3} \mathrm{SIZE}_{\mathrm{jt}}+\varepsilon_{\mathrm{jt}} \\
& \text { Model 3A: } \mathrm{ROA}_{\mathrm{jt}}=\alpha_{\mathrm{jt}}+\beta_{1} \mathrm{HCE}_{\mathrm{jt}}+\beta_{2} \mathrm{LEVERAGE}_{\mathrm{jt}}+\beta_{3} \mathrm{SIZE}_{\mathrm{jt}}+\varepsilon_{\mathrm{jt}} \\
& \text { Model 3B: ROE }=\alpha_{\mathrm{jt}}+\beta_{1} \mathrm{HCE}_{\mathrm{jt}}+\beta_{2} \mathrm{LEVERAGE}_{\mathrm{jt}}+\beta_{3} \mathrm{SIZE}_{\mathrm{jt}}+\varepsilon_{\mathrm{jt}} \\
& \text { Model 4A: ROA }=\alpha_{\mathrm{jt}}+\beta_{1} \mathrm{SCE}_{\mathrm{jt}}+\beta_{2} \mathrm{LEVERAGE}_{\mathrm{jt}}+\beta_{3} \mathrm{SIZE}_{\mathrm{jt}}+\varepsilon_{\mathrm{jt}} \\
& \text { Model 4B: ROE }=\alpha_{\mathrm{jt}}+\beta_{1} \mathrm{SCE}_{\mathrm{jt}}+\beta_{2} \mathrm{LEVERAGE}_{\mathrm{jt}}+\beta_{3} \mathrm{SIZE}_{\mathrm{jt}}+\varepsilon_{\mathrm{jt}}
\end{aligned}
$$

where:

$\mathrm{ROA}_{j t}$ or $\mathrm{ROE}_{j t}=$ Profitability (i.e. the measure of performance) of Islamic bank $j$ in year $t$;

\begin{tabular}{|c|c|c|c|c|c|c|c|c|c|}
\hline & $\mathrm{CEE}$ & $\mathrm{HCE}$ & $\mathrm{SCE}$ & VAIC & SIZE & LEVERAGE & $\mathrm{ROA}$ & $\mathrm{ROE}$ & \\
\hline Mean & 0.017 & 3.562 & 0.852 & 4.398 & 172050.820 & 3.651 & 0.028 & 0.002 & \\
\hline Median & 0.040 & 2.979 & 0.875 & 3.697 & 59121.000 & 3.441 & 0.007 & 0.020 & \\
\hline Std deviation & 0.285 & 11.152 & 0.527 & 11.332 & 253663.842 & 3.316 & 0.138 & 0.218 & \\
\hline Skewness & -2.387 & 0.837 & 0.185 & 0.793 & 1.943 & 0.601 & -2.878 & -2.302 & \\
\hline Std error of skewness & 0.250 & 0.250 & 0.250 & 0.250 & 0.251 & 0.250 & 0.250 & 0.250 & Table II. \\
\hline Kurtosis & 10.006 & 6.337 & 9.337 & 6.301 & 2.874 & -0.480 & 12.112 & 8.023 & Descriptive statistics \\
\hline Std error of kurtosis & 0.495 & 0.495 & 0.495 & 0.495 & 0.498 & 0.495 & 0.495 & 0.495 & of the variables \\
\hline
\end{tabular}

VAIC $_{j t} \quad=$ Value-added intellectual coefficient of Islamic bank $j$ in year $t$; and

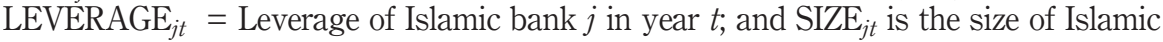
bank $j$ in year $t$.

\section{Results and discussion}

5.1 Descriptive statistics and correlation analysis

Tables II and III report the descriptive statistics and the correlation matrix, respectively. The VAIC mean for Islamic banks operating in the GCC countries is 4.398
An analysis of the GCC banks 


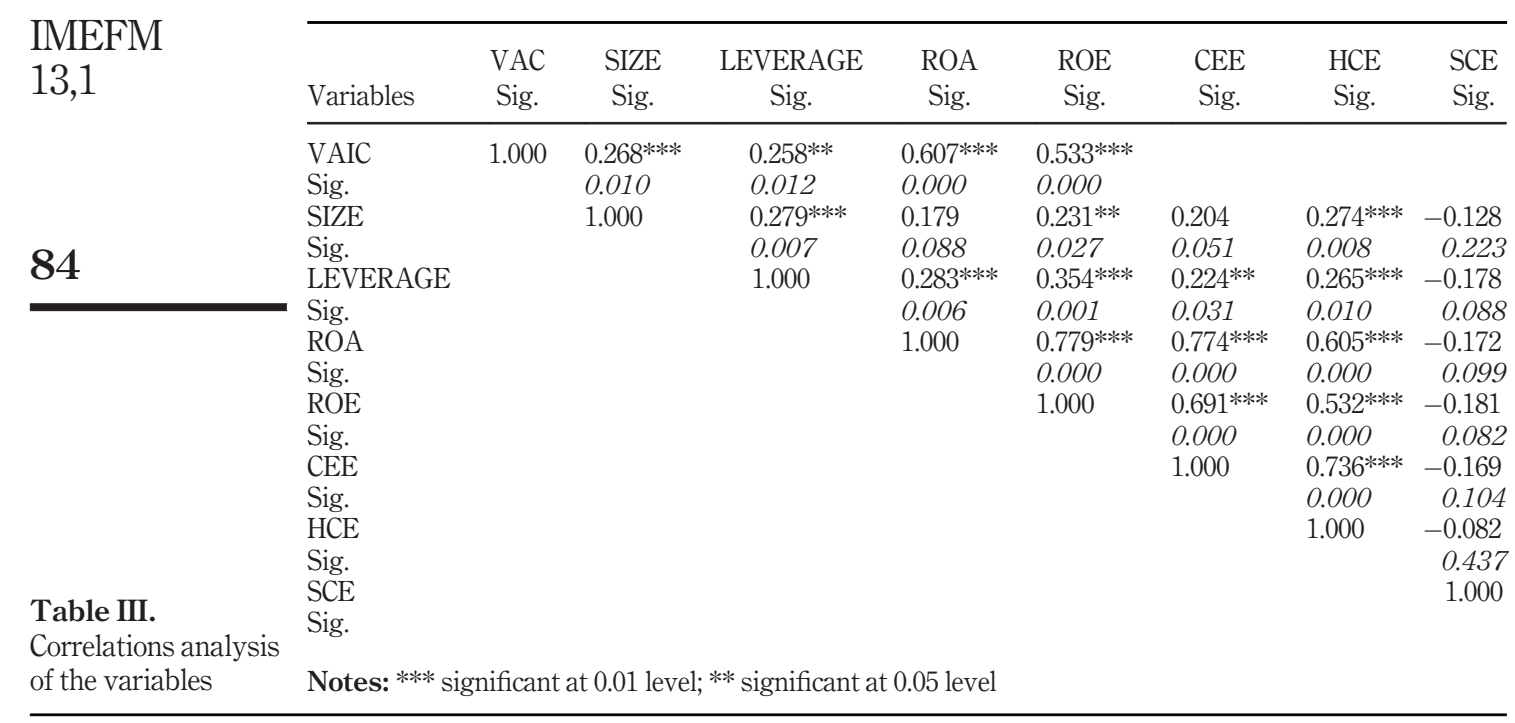

(Table II). This is lower than the means reported in prior studies in Islamic banks operating in other countries such as Pakistan and Malaysia (Latif et al., 2012; Ousama and Fatima, 2015). The components of the VAIC also show means lower than what has been reported in previous research (Ousama and Fatima, 2015) with 0.017, 3.562 and 0.852 , respectively, for CEE, HCE and SCE. This may suggest that the Islamic banks in the GCC countries are not using their IC to its full potential. This could be because of the fact that IC is still in the expansion phase in most developing countries including the GCC countries.

On the other hand, the HCE has the highest mean among the three components of the VAIC (3.562). This could be a preliminary indication of the importance given by Islamic banks on the efficient use of their $\mathrm{HC}$ compared to $\mathrm{CE}$ and SC. This finding is consistent with Ousama and Fatima (2015) who reached a similar preliminary conclusion for Islamic banks in Malaysia as did Al-Musali and Ismail (2014) for Saudi Arabia and Goh (2005) for conventional banks in Malaysia.

Table III shows the results of the correlation analysis. Under the univariate correlation, financial performance measures are related positively (statistically significant correlation) to the VAIC construct and its components with the exception of SCE (negative non-statistically significant relation for both ROA and ROE). The positive relationship between ROA, ROE, VAIC, CEE and HCE suggests that the Islamic bank's financial performance is positively associated with the organisation's IC and its $\mathrm{CE}$ and $\mathrm{HC}$, but not the SC. Furthermore, with regard to the control variables, the leverage has a significant positive relationship with the CEE and the HCE, whereas size only shows a significant relationship with the HCE.

\subsection{Regression analysis}

Tables IV-VII report the results of the regression analysis of the six models. The financial performance is expected to be influenced by the IC (i.e. VAIC) and its components (i.e. CEE, $\mathrm{HCE}$ and $\mathrm{SCE}$ ). The models are a good fit (F significant). 
5.2.1 Value added intellectual coefficient analysis. Table IV presents the results of the regression analysis of the VAIC with ROA and ROE[2]. The explanatory power of Models $1 \mathrm{~A}$ and $1 \mathrm{~B}$ are relatively important. The adjusted $R^{2}$ are 36.5 and 31.2 per cent for Models $1 \mathrm{~A}$ and $1 \mathrm{~B}$, respectively. The coefficient on VAIC is significantly positive for both regressions (ROA and $\mathrm{ROE}$ ). These findings corroborate the initial findings of the correlation analysis. It aligns with literature supporting the idea that IC positively impacts financial performance (Goh, 2005; Kamath, 2007; Rehman et al., 2012; Al-Musali and Ku Ismail, 2014; Ousama and Fatima, 2015; Ahmad and Ahmed, 2016; Nawaz and Haniffa, 2017). The empirical findings favour $H 1$. Hence, $H 1$ is supported. None of the control variables are statistically significant in Model $1 \mathrm{~A}$, while only leverage is significant in Model 1B.

5.2.2 Capital employed efficiency, human capital efficiency and structural capital efficiency analysis. Tables V and VI present the results for $\mathrm{H} 2$ and H3. The findings show that the $\mathrm{CEE}$ and the HCE have a positive and significant relationship with the ROE and the ROA. The explanatory powers (adjusted $R^{2}$ ) of the models (Models 2 and 3 ) are also high.

These results suggest that using the capital efficiently and combined with the efficient use of $\mathrm{HC}$ in Islamic banks have a positive influence on their financial performance. Therefore, $\mathrm{H} 2$ and $H 3$ are supported. The findings of the CEE and the HCE are consistent with the findings of previous studies (Latif et al., 2012; Al-Musali and Ku Ismail, 2014; Ousama and Fatima, 2015; Setianto and Sukmana, 2016; Nawaz and Haniffa, 2017).

Nonetheless, the empirical investigation failed to support any significant relationship between the SCE and both financial performance proxies as showed in Table VII. Therefore, $H 4$ is not supported by the empirical data. This finding aligns with the results of the correlation analysis of the SCE reported in Table III. In addition, it is consistent with the findings of Setianto and Sukmana (2016) and Nawaz and Haniffa (2017).

\begin{tabular}{|c|c|c|c|c|c|}
\hline \multirow[b]{2}{*}{ Variables } & \multicolumn{2}{|c|}{ ROA } & \multicolumn{2}{|c|}{ ROE } & \\
\hline & Coefficient & $t$-statistic & Coefficient & $t$-statistic & \\
\hline (Constant) & -0.079 & -4.434 & -0.102 & -3.473 & \\
\hline VAIC & 0.575 & $6.508^{* * * *}$ & 0.463 & $5.034^{* * * *}$ & Table IV. \\
\hline SIZE & -0.015 & -0.165 & 0.045 & 0.486 & Regression analysis \\
\hline LEVERAGE & 0.140 & 1.575 & 0.221 & $2.397 * *$ & $\begin{array}{l}\text { Kegression analysis } \\
\text { results: Model } 1 \text { (A }\end{array}$ \\
\hline Adjusted $R^{2}$ & 0.365 & & 0.312 & & results: Ilodel 1 (A \\
\hline$F$ value & $18.432 * * *$ & & $14.744^{* * * *}$ & & $\begin{array}{l}\text { and B) for financial } \\
\text { performance }\end{array}$ \\
\hline \multicolumn{5}{|c|}{ Notes: *** significant at 0.01 level; ** significant at 0.05} & and VAIC \\
\hline
\end{tabular}

\begin{tabular}{|c|c|c|c|c|c|}
\hline \multirow[b]{2}{*}{ Variables } & \multicolumn{2}{|c|}{ ROA } & \multicolumn{2}{|c|}{ ROE } & \\
\hline & Coefficient & $t$-statistic & Coefficient & $t$-statistic & \\
\hline Constant & -0.039 & -2.677 & -0.048 & -1.884 & \\
\hline $\mathrm{CEE}$ & 0.749 & $10.849 * * *$ & 0.637 & $8.317^{* * * *}$ & Table V \\
\hline SIZE & -0.006 & -0.089 & 0.047 & 0.599 & $\begin{array}{l}\text { I able V. } \\
\text { Reoression }\end{array}$ \\
\hline LEVERAGE & 0.116 & 1.649 & 0.196 & $2.508^{* *}$ & Regression analysis \\
\hline Adjusted $R^{2}$ & 0.598 & & 0.504 & & results: Model 2 (A \\
\hline$F$ value & $46.042^{* * *}$ & & $31.786^{* * * *}$ & & $\begin{array}{l}\text { and B) for financial } \\
\text { performance }\end{array}$ \\
\hline \multicolumn{5}{|c|}{ Notes: *** significant at 0.01 level; ** significant at 0.05} & and CEE \\
\hline
\end{tabular}


IMEFM

13,1

86

\section{Table VI.}

Regression analysis results: Model 3 (A and $\mathrm{B})$ for financial performance and HCE

\subsection{Discussion of results}

The results of this study reveal how Islamic banks pay attention to their IC. First, the empirical analysis shows that Islamic banks reported a lower level of IC efficiency compared to other studies in countries such as Malaysia (Ousama and Fatima, 2015) and Pakistan (Latif et al., 2012). This result should be interpreted with caution as the study is examining different settings, with different regulations and legal systems. Malaysia, for instance, has positioned itself as the hub for Islamic finance. Also, several universities and institutes offer undergraduate (diploma and bachelor) and postgraduate (Masters and $\mathrm{PhDs}$ ) studies in Islamic finance. The abundance of skilled manpower in Islamic banking in Malaysia has made its $\mathrm{HC}$ stronger than other parts of the world.

For the GCC countries, despite the presence of Islamic laws in several aspects of daily life, the presence of a skilled workforce in Islamic finance is still lagging. The education alternatives in Islamic finance are scarce and not up to the level of more established universities and programs such as in Malaysia and Indonesia for instance. Nevertheless, looking closely at the relationship between the overall IC (i.e. VAIC) and financial performance (i.e. ROA and ROE), the results indicate that IC positively affects banks' financial performance. Islamic banks have specific requirements regarding the $\mathrm{CE}$ and human resources they require. Besides the financial background, the ideal profile of human resources in Islamic banks is somebody with a background in Islamic finance, law and legislation. Both Islamic and conventional banks strongly emphasise the importance of IC as a booster of their financial performance. More specifically, the study of how the components of IC affect profitability showed that only the CE and the $\mathrm{HC}$ positively affect the banks' financial performance. The analysis failed to confirm a positive relationship between the SC and the financial performance. These findings reveal that the capacity of Islamic banks to create value mainly depends on the $\mathrm{HC}$ and the $\mathrm{CE}$. This is not

\begin{tabular}{|c|c|c|c|c|}
\hline \multirow[b]{2}{*}{ Variables } & \multicolumn{2}{|c|}{ ROA } & \multicolumn{2}{|c|}{ ROE } \\
\hline & Coefficient & $t$-statistic & Coefficient & $t$-statistic \\
\hline Constant & -0.073 & -4.082 & -0.094 & -3.204 \\
\hline HCE & 0.574 & $6.458^{* * * *}$ & 0.462 & $4.999 * * *$ \\
\hline SIZE & -0.017 & -0.185 & 0.044 & 0.469 \\
\hline LEVERAGE & 0.137 & 1.539 & 0.219 & $2.367 * *$ \\
\hline Adjusted $R^{2}$ & 0.362 & & 0.310 & \\
\hline$F$ Value & $18.195^{* * * *}$ & & $14.606^{* * * *}$ & \\
\hline
\end{tabular}

Notes: *** significant at 0.01 level; ** significant at 0.05

\section{Table VII.}

Regression analysis results: Model 4

(A and B) for financial performance and SCE

\begin{tabular}{|c|c|c|c|c|}
\hline \multirow[b]{2}{*}{ Variables } & \multicolumn{2}{|c|}{ ROA } & \multicolumn{2}{|c|}{ ROE } \\
\hline & Coefficient & $t$-statistic & Coefficient & $t$-statistic \\
\hline Constant & -0.047 & -1.384 & -0.055 & -1.052 \\
\hline SCE & -0.118 & -1.151 & -0.111 & -1.111 \\
\hline SIZE & 0.098 & 0.930 & 0.134 & 1.313 \\
\hline LEVERAGE & 0.235 & $2.210^{* * *}$ & 0.295 & $2.866^{* * * *}$ \\
\hline Adjusted $R^{2}$ & 0.073 & & 0.126 & \\
\hline$F$ value & 3.397 ** & & 5.368 **** & \\
\hline
\end{tabular}


surprising as the banking industry is a service-based sector where $\mathrm{HC}$ is an essential asset. In addition, the findings shed light on the urgent need to give more attention to SC. The value creation of SC is vital for the banks if they are seriously seeking sustainable growth. Realising the value of technological knowledge (the know-how) and how to maintain it is one of the important dimensions that should be taken into consideration (Mehralian et al., 2012).

The findings of the study can be inserting and beneficial to the relevant policymaking authorities (e.g. legislators, central banks, standards setters and stock exchanges) in the GCC countries. They could use them for policy reforms to enhance the efficiency of resource the GCC banks usage and performance improvement.

Overall, the findings of this research suggest that more effort should be addressed to IC to improve financial performance in the Islamic banking industry in the GCC countries. The research provides a preliminary seed to further explore the place of IC in the finance industries such as Islamic banking. Further studies are needed at this level.

\section{Conclusion}

The Islamic banking industry is a fast-growing sector catching researchers' attention from a variety of perspectives. Financial performance remains one of the key issues that regulators and managers alike are looking into and striving to list the variables that could boost performance. IC has a proven influence on the financial performance of conventional (Goh, 2005) and Islamic banks (Al-Musali and Ku Ismail, 2014; Ousama and Fatima, 2015). To date, few studies explored this subject with the attention it deserves. The current study adds to this stream by investigating the impact of IC efficiency on the financial performance of the Islamic banks operating in the GCC countries. It was found that IC has a significant positive impact on the financial performance of Islamic banks. Also, $\mathrm{CE}$ and $\mathrm{HC}$ have significant impacts on the financial performance compared to $\mathrm{SC}$ which has no effects.

The study has implications for knowledge, practice and policymaking. Concerning the field of knowledge, the study adds to the literature by focusing on Islamic banks in a highly concentrated Islamic banking industry (i.e. GCC countries). For practice (i.e. practitioners in the Islamic banking industry in the GCC countries), the findings reflect the current extent of IC and its components. This will help to understand the strength of Islamic banks to improve performance and create value through efficient use of IC. The Islamic banks in the GCC can use their $\mathrm{CE}$ and $\mathrm{HC}$ efficiently. However, their inability to optimise their SC requires specially formulated strategies. For policymaking, the findings guide the relevant authorities (e.g. legislators, central banks and stock exchanges) towards emphasising strategic reforms. This is important as most of the GCC countries plan to diversify their economies and transform to a knowledge-based economy where IC will play a major role in improving firm performance. In addition, the results help regulators in Bahrain, Qatar and UAE, especially as they are looking forward to becoming financial hubs for Islamic finance.

The study has several limitations. Firstly, the research sample excluded banks operating in Oman because of non-availability of data at the time of the research. Even though the Omani market is not as developed as its peers in the other GCC countries, the addition of the few Omani banks in the future could improve the findings. Secondly, the research period is limited to three years. Longer periods would possibly offer more conclusive results. Thirdly, the findings relied on quantitative analysis (regressions) which is insufficient for a rich picture of the GCC markets. GCC countries are fast emerging, and the strategies adopted by financial institutions are heavily influenced by chief executive officers and decision-makers who are often appointed to concretise the government's economic strategies. Therefore, more qualitative analysis is required (interviews with key decision-makers) to understand the position of IC in the financial industry better. 
IMEFM

13,1

\section{8}

\section{Notes}

1. The model has been used in several prior studies. For example: Chen et al. (2005), Maditinos et al. (2011) and Al-Musali and Ku Ismail (2014).

2. Prior to performing the regression analysis, multicollinearity was checked. Table III (i.e. correlation analysis) shows that the highest correlation coefficient was 0.779 which is less than 0.80 ; hence the problem does not exist.

\section{References}

Abdull Razak, R., Mohammad, J. and Tobiagi, S.M. (2016), "Intellectual capital disclosure practices and intellectual capital performance in Saudi Arabia financial institution”, Journal of Business Studies Quarterly, Vol. 7 No. 4, pp. 1-14.

Abdulsalam, F., Al-Qaheri, H. and Al-Khayyat, R. (2011), "The intellectual capital performance of kuwaiti banks: an application of VAIC model”, iBusiness, Vol. 3 No. 1, pp. 88-96.

Ahmad, M. and Ahmed, N. (2016), “Testing the relationship between intellectual capital and a firm's performance: an empirical investigation regarding financial industries of Pakistan", International Journal of Learning and Intellectual Capital, Vol. 13 No. 2/3, pp. 250-272.

Ahuja, B.R. and Ahuja, N.I. (2012), "Intellectual capital approach to performance evaluation: a case study of the banking sector in India”, International Research Journal of Finance and Economics, Vol. 93, pp. 110-122.

Al-Hassan, A., Khamis, M. and Oulidi, N. (2010), "The GCC banking sector: topography and analysis”, Working Paper, (No. WP/10/87), International Monetary Fund.

Al-Ibrahim, Y. (2004), A Radical Reform of the Cooperation Council of Arab Gulf States, Dar Kurtas.

Al-Kuwari, D. (2013), "Mission impossible? Genuine economic development in the Gulf cooperation council countries”, Research Paper, Kuwait Programme on Development, Governance and Globalisation in the Gulf States, London School of Economics and Political Science (LSE).

Al-Musali, M.A.K. and Ku Ismail, K.N.I. (2012a), "Corporate governance, bank specific characteristics, banking industry characteristics, and intellectual Capital (IC) performance of banks in arab Gulf cooperation council (GCC) countries", Asian Academy of Management Journal of Accounting and Finance, Vol. 8 No. 1, pp. 115-135.

Al-Musali, M.A.K. and Ku Ismail, K.N.I. (2012b), "Intellectual Capital performance and board characteristics of GCC banks”, GSTF Business Review, Vol. 2 No. 1, pp. 80-86.

Al-Musali, M.A.K. and Ku Ismail, K.N.I. (2014), "Intellectual Capital and its effects on financial performance of banks: evidence from Saudi Arabia”, Procedia - Social and Behavioral Sciences, Vol. 164, pp. 201-207.

Al-Musali, M.A.K. and Ku Ismail, K.N.I. (2016), "Cross-country comparison of intellectual Capital performance and its impact on financial performance of commercial banks in GCC countries", International Journal of Islamic and Middle Eastern Finance and Management, Vol. 9 No. 4, pp. 512-531.

Bain and Company (2013), "Opportunities and Challenges for the Development of Islamic Finance Hubs: A New Strategy for Paris", PowerPoint presentation, Greater Paris Investment Agency, Paris.

Barney, J. (1991), "Firm resources and sustained competitive advantage", Journal of Management, Vol. 17 No. 1, pp. 99-120.

Beattie, V. and Thomson, S. (2007), "Lifting the lid on the use of content analysis to investigate intellectual Capital disclosures", Accounting Forum, Vol. 31 No. 2, pp. 129-163.

Beltratti, A. and Stulz, R.M. (2012), "The credit crisis around the globe: why did some banks perform better?”, Journal of Financial Economics, Vol. 105 No. 1, pp. 1-17. 
Berger, A.N. and Bouwman, C.H. (2013), "How does capital affect bank performance during financial crises?", Journal of Financial Economics, Vol. 109 No. 1, pp. 146-176.

Bhartesh, K.R. and Bandyopadhyay, A.K. (2005), "Intellectual Capital: concept and its measurement", Finance India, Vol. 19 No. 4, pp. 1365-1374.

Bontis, N., Keow, W.C.K. and Richardson, S. (2000), "Intellectual capital and business performance in malaysian industries", Journal of Intellectual Capital, Vol. 1 No. 1, pp. 85-100.

Borkowski, S.C., Welsh, M.J. and Kristin, W. (2010), "Johnson and johnson: a model for sustainability reporting", Strategic Finance, pp. 29-37.

Brooking, A. (1996), Intellectual Capital, International Thomson Business Press, London.

Chan, K., H. (2009a), "Impact of intellectual Capital on organizational performance: an empirical study of companies in the hang seng index (part 1)", The Learning Organization, Vol. 16 No. 1, pp. 4-12.

Chan, K., H. (2009b), "Impact of intellectual Capital on organizational performance: an empirical study of companies in the hang seng index (part 2)", The Learning Organization, Vol. 16 No. 1, pp. 22-39.

Chen, M., Cheng, S. and Hwang, Y. (2005), "An empirical investigation of the relationship between intellectual capital and firms' market value and financial performance", Journal of Intellectual Capital, Vol. 6 No. 2, pp. 159-179.

Chen, L., Danbolt, J. and Holland, J. (2014), "Rethinking bank business models: the role of intangibles", Accounting, Auditing and Accountability Journal, Vol. 27 No. 3, pp. 563-589.

Chu, S.K.W., Chan, K.H. and Wu, W.W.Y. (2011), "Charting intellectual Capital performance of the gateway to China", Journal of Intellectual Capital, Vol. 12 No. 2, pp. 249-276.

Cihak, M. and Hesse, H. (2008), "Islamic banks and financial stability: an empirical analysis", Working Paper (No. WP/08/16), International Monetary Fund.

Clarke, M., Seng, D. and Whiting, R.H. (2011), "Intellectual Capital and firm performance in Australia", Journal of Intellectual Capital, Vol. 12 No. 4, pp. 505-530.

Cohen, S. and Kaimenakis, N. (2007), "Intellectual Capital and corporate performance in knowledgeintensive SMEs", The Learning Organization, Vol. 14 No. 3, pp. 241-262.

De Brentani, U. and Kleinschmidt, E.J. (2004), "Corporate culture and commitment: impact on performance of international new product development programs", Journal of Product Innovation Management, Vol. 21 No. 5, pp. 309-333.

De Castro, G.M. and Sáez, P.L. (2008), "Intellectual Capital in high-tech firms: the case of Spain”, Journal of Intellectual Capital, Vol. 9 No. 1, pp. 25-36.

Deng, Z., Lev, B. and Narin, F. (1999), "Science and technology as predictors of stock performance", Financial Analysts Journal, Vol. 55 No. 3, pp. 20-32.

Edvinsson, L. and Malone, M. (1997), Intellectual Capital: Realizing Your Company True Value by Finding Its Hidden BrainPower, Harper Business, New York, NY.

El Saadani, A., Reppel, O. and Gibson, M. (2011), "Banking in the Gulf cooperation council in 2015: embracing and leveraging change", Accenture, Abu Dhabi.

El-Bannany, M. (2008), "A study of determinants of intellectual Capital performance in banks: the UK case”, Journal of Intellectual Capital, Vol. 9 No. 3, pp. 487-498.

El-Bannany, M. (2012), "Global financial crisis and the intellectual Capital performance of UAE banks", Journal of Human Resource Costing and Accounting, Vol. 16 No. 1, pp. 20-36.

El-Quqa, O.M., Dash, S., Bokade, P., Sarma, R. and Hasan, F. (2005), GCC Banking Sector, Global Investment House, Kuwait.

Firer, S. and Williams, S. (2003), "Intellectual Capital and traditional measures of corporate performance”, Journal of Intellectual Capital, Vol. 4 No. 3, pp. 348-360.

Florin, J., Lubatkin, M. and Schulze, W. (2003), "A social Capital model of high-growth ventures", Academy of Management Journal, Vol. 46 No. 3, pp. 374-384. 
IMEFM 13,1

Gan, K. and Saleh, Z. (2008), "Intellectual Capital and corporate performance of technology-intensive companies: Malaysia evidence”, Asian Journal of Business and Accounting, Vol. 1 No. 1, pp. 113-130.

Garcia-Meca, E. (2005), "Bridging the gap between disclosure and use of intellectual capital information", Journal of Intellectual Capital, Vol. 6 No. 3, pp. 427-440.

Goh, P.C. (2005), "Intellectual capital performance of commercial banks in Malaysia", Journal of Intellectual Capital, Vol. 6 No. 3, pp. 385-396.

Guerrini, A., Romano, G. and Leardini, C. (2014), "Does intellectual Capital efficiency affect financial performance? The case of Italian listed firms", International Journal of Learning and Intellectual Capital, Vol. 11 No. 2, pp. 127-148.

Guthrie, J., Petty, R. and Ricceri, F. (2006), "The voluntary reporting of intellectual capital: comparing evidence from Hong Kong and Australia", Journal of Intellectual Capital, Vol. 7 No. 2, pp. 254-271.

Guthrie, J., Petty, R. and Ricceri, F. (2007), Intellectual Capital Reporting: Lessons from Hong Kong and Australia, The Institute of Chartered Accountants of Scotland, Edinburgh.

Hassan, K. and Zaher, T. (2001), "A comparative literature survey of Islamic finance and banking”, Financial Markets, Institutions and Instruments, Vol. 10 No. 4, pp. 155-199.

Ho, Y. and Liau, Y. (2014), "Shariah study lures Non Muslim students in Asia: Islamic finance", Consulté 11 Novembre, à l'adresse.

Holland, J. (2003), "Intellectual capital and the capital market - Organisation and competence", Accounting, Auditing and Accountability Journal, Vol. 16 No. 1, p. 39.

Holland, J. (2010), "Banks, knowledge and crisis: a case of knowledge and learning failure”, Journal of Financial Regulation and Compliance, Vol. 18 No. 2, pp. 87-105.

Holmes, Z. and Kathpalia, S. (2014), Islamic Finance Outlook 2014 Edition", Standard and Poor's Ratings Services, McGraw Hill Financial.

Hsu, L.C. and Wang, C.H. (2012), "Clarifying the effect of intellectual Capital on performance: the mediating role of dynamic capability", British Journal of Management, Vol. 23 No. 2, pp. 179-205.

Hvidt, M. (2013), "Economic diversification in GCC countries: past record and future trends", Research Paper, Kuwait Programme on Development, Governance and Globalisation in the Gulf States, The London School of Economics and Political Science.

Iazzolino, G. and Laise, D. (2013), "Value added intellectual coefficient (VAIC): a methodological and critical review", Journal of Intellectual Capital, Vol. 14 No. 4, pp. 547-563.

Institute of Management Accountants - IMA (2010), "Unrecognized Intangible Assets: Identification, Management, and Reporting", Institute of Management Accountants (IMA), NJ.

Joshi, M., Cahill, D. and Sidhu, J. (2010), "Intellectual Capital performance in the banking sector: an assessment of Australian owned banks", Journal of Human Resource Costing and Accounting, Vol. 14 No. 2, pp. 151-170.

Kamath, B. (2007), "The intellectual capital performance of Indian banking sector", Journal of Intellectual Capital, Vol. 8 No. 1, pp. 96-123.

Kamath, B. (2008), “Intellectual capital disclosure in India: content analysis of 'teck' firms”, Journal of Human Resource Costing and Accounting, Vol. 12 No. 3, pp. 213-224.

Khalique, M., Shaari, J.A.N., Md. Isa, A.H. and Samad, N. (2013), "Impact of intellectual Capital on the organizational performance of Islamic banking sector in Malaysia", Asian Journal of Finance and Accounting, Vol. 5 No. 2, pp. 75-83.

Lajili, K. and Z"Eghal, D. (2005), "Labor cost voluntary disclosures and firm equity values: ishuman capital information value-relevant?", Journal of International Accounting, Auditing and Taxation, Vol. 14 No. 2, pp. 121-138. 
Latif, M., Malik, M.S. and Aslam, S. (2012), "Intellectual Capital efficiency and corporate performance in developing countries: a comparison between Islamic and conventional banks in Pakistan", Interdisciplinary Journal of Contemporary Research in Business, Vol. 4 No. 1, pp. 405-420.

Lev, B. and Zarowin, P. (1999), "The boundaries of financial reporting and how to extend them”, Journal of Accounting Research, Vol. 37 No. 2, pp. 353-385.

Maditinos, D., Chatzoudes, D., Tsairidis, C. and Theriou, G. (2011), "The impact of intellectual capital on firm's market value and financial performance”, Journal of Intellectual Capital, Vol. 12 No. 1, pp. 132-151.

Makki, M.A.M. and Lodhi, S.A. (2008), "Impact of intellectual Capital efficiency on profitability: a case study of LSE25 companies", The Labore Journal of Economics, Vol. 13 No. 2, pp. 81-98.

Marr, B., Gray, D. and Neely, A. (2003), "Why do firms measure their intellectual Capital", Journal of Intellectual Capital, Vol. 4 No. 4, pp. 441-464.

Marshall, R., Talbott, J. and Bukovinsky, D. (2006), "Employee empowerment works at small companies, too", Strategic Finance, Vol. 88 No. 3, pp. 34-39.

Mehralian, G., Rajabzadeh, A., Sadeh, M.R. and Rasekh, H.R. (2012), "Intellectual Capital and corporate performance in iranian pharmaceutical industry", Journal of Intellectual Capital, Vol. 13 No. 1, pp. 138-158.

MERITUM (2002), Guidelines for Managing and Reporting on Intangibles, Madrid.

Mondal, A. and Ghosh, S.K. (2012), "Intellectual Capital and financial performance of Indian banks", Journal of Intellectual Capital, Vol. 13 No. 4, pp. 515-530.

Murthy, V. and Mouritsen, J. (2011), "The performance of intellectual capital: mobilising relationships between intellectual and financial Capital in a bank", Accounting, Auditing and Accountability Journal, Vol. 24 No. 5, pp. 622-646.

Nawaz, T. (2017), "Intellectual Capital, financial crisis and performance of Islamic banks: does Shariah governance matter?", International Journal of Business and Society, Vol. 18 No. 1, pp. 211-226.

Nawaz, T. and Haniffa, R. (2017), "Determinants of financial performance of Islamic banks: an intellectual capital perspective", Journal of Islamic Accounting and Business Research, Vol. 8 No. 2, pp. 130-142.

Organisation for Economic Co-operation and Development - OECD (2007), Policy Brief: Creating Value from Intellectual Assets, OECD, Paris.

Ousama, A.A. and Fatima, A.H. (2015), "Intellectual Capital and financial performance of Islamic banks", International Journal of Learning and Intellectual Capital, Vol. 4 No. 2, pp. 159-179.

Ousama, A.A., Fatima, A.H. and Hafiz-Majdi, A.R. (2011a), "Usefulness of intellectual Capital information: prepares' and users' views", Journal of Intellectual Capital, Vol. 12 No. 3, pp. 430-445.

Ousama, A.A., Fatima, A.H. and Hafiz-Majdi, A.R. (2011b), "Effects of intellectual capital information disclosed in annual reports on market capitalization: evidence from bursa Malaysia”, Journal of Human Resource Costing and Accounting, Vol. 15 No. 2, pp. 85-101.

Ozkan, N., Cakan, S. and Kayacan, M. (2016), "Intellectual Capital and financial performance: a study of the Turkish banking sector", Borsa Istanbul Review, Vol. 20, pp. 1-9.

Pal, K. and Soriya, S. (2012), "IC performance of Indian pharmaceutical and textile industry", Journal of Intellectual Capital, Vol. 13 No. 1, pp. 120-137.

Pastré, O. and Gecheva, K. (2008), "La finance islamique à la croisée des chemins", Revue D'économie Financière, Vol. 92 No. 2, pp. 197-213.

Petty, R. and Guthrie, J. (2000), "Intellectual capital literature review: measurement, reporting and management”, Journal of Intellectual Capital, Vol. 1 No. 2, pp. 155-176.

Pike, S. and Roos, G. (2004), "Mathematics and modern business management", Journal of Intellectual Capital, Vol. 5 No. 2, pp. 243-256. 
IMEFM 13,1

Pulic, A. (1998), "Measuring the performance of intellectual potential in knowledge economy", available at: www.vaic-on.net/start.htm (accessed 28 February 2012).

Pulic, A. (2000), "MVA and VAIC ${ }^{\mathrm{TM}}$ analysis of randomly selected companies from FTSE250", available at: www.vaic-on.net/start.htm (accessed 28 February 2012).

Rehman, W., Rehman, H., Usman, M. and Asghar, N. (2012), "A link of intellectual capital performance with corporate performance: comparative study form banking sector in Pakistan", International Journal of Business and Social Science, Vol. 3 No. 12, pp. 313-321.

Riahi-Belkaoui, A. (2003), "Intellectual Capital and firm performance of US multinational firms: a study of the resource-based and stakeholder views", Journal of Intellectual Capital, Vol. 4 No. 2, pp. 215-226.

Ruta, C.D. (2009), "HR portal alignment for the creation and development of intellectual capital", The International Journal of Human Resource Management, Vol. 20 No. 3, pp. 562-577.

Setianto, R.H. and Sukmana, R. (2016), "Intellectual capital and Islamic banks' performance; evidence from Indonesia and Malaysia", IQTISHADIA Jurnal Kajian Ekonomi Dan Bisnis Islam, Vol. 9 No. 2, pp. 376-397.

Shih, K., Chang, C. and Lin, B. (2010), "Assessing knowledge creation and intellectual Capital in banking industry", Journal of Intellectual Capital, Vol. 11 No. 1, pp. 74-89.

Stewart, T.A. (1997), Intellectual Capital: The New Wealth of Organizations, Doubleday, New York, NY.

Striukova, L., Unerman, J. and Guthrie, J. (2008), "Corporate reporting of intellectual capital: evidence from UK companies”, The British Accounting Review, Vol. 40 No. 4, pp. 297-313.

Sullivan, P.H. (2000), Value-Driven Intellectual Capital: How to Convert Intangible Corporate Assets into Market Value, John Wiley and Sons.

Sveiby, K.E. (2007), "Methods for measuring intangible assets", available at: www.sveiby.com/Portals/ 0/articles/IntangibleMethods.htm (accessed January 8, 2009).

Tan, H.P., Plowman, D. and Hancock, P. (2007), "Intellectual capital and financial returns of companies", Journal of Intellectual Capital, Vol. 8 No. 1, pp. 76-95.

The Economist Group (2009), "Annual report 2009", The Economist Group.

Wang, M.S. (2011), "Intellectual Capital and firm performance", Paper presented at the Annual Conference on Innovations in Business and Management, London.

White, G., Lee, A. and Tower, G. (2007), "Drivers of voluntary intellectual Capital disclosure in listed biotechnology companies", Journal of Intellectual Capital, Vol. 8 No. 3, pp. 517-537.

Whiting, R.H. and Woodcock, J. (2011), "Firm characteristics and intellectual capital disclosure by Australian companies", Journal of Human Resource Costing and Accounting, Vol. 15 No. 2, pp. 102-126.

Wilson, R. (2009), "The development of Islamic finance in the GCC", Working Paper, Kuwait Programme on Development, Governance and Globalisation in the Gulf States, The Centre for the Study of Global Governance.

World Bank (2013), “Annual report 2013”, World Bank, Washington, DC.

World Intellectual Capital Initiative - WICI (2011), "WICI concept paper”, World Intellectual Capital Initiative (WICI).

Yalama, A. and Coskun, M. (2007), "Intellectual Capital performance of quoted banks on the Istanbul stock exchange market”, Journal of Intellectual Capital, Vol. 8 No. 2, pp. 256-271.

Yang, C. and Lin, C.Y. (2009), "Does intellectual Capital mediate the relationship between HRM and organizational performance? Perspective of a healthcare industry in Taiwan", The International Journal of Human Resource Management, Vol. 20 No. 9, pp. 1965-1984.

Youndt, M.A., Subramaniam, M. and Snell, S.A. (2004), "Intellectual Capital profiles: an examination of investments and returns", Journal of Management Studies, Vol. 41 No. 2, pp. 335-361. 
Zanjirdar, M. and Kabiribalajadeh, A. (2011), "Examining relationship between ownership structure and performance of intellectual Capital in the stock market of Iran", Indian Journal of Science and Technology, Vol. 4 No. 10, pp. 1369-1377.

An analysis of the GCC banks

Zeghal, D. and Maaloul, A. (2010), "Analysing value added as an indicator of intellectual Capital and its consequences on company performance", Journal of Intellectual Capital, Vol. 11 No. 1, pp. 39-60.

Zou, X. and Huan, T. (2011), "A study of the intellectual capital's impact on listed banks' performance in China”, African Journal of Business Management, Vol. 5 No. 12, pp. 5001-5009.

\section{Further reading}

Bontis, N. (2001), "Assessing knowledge assets: a review of the models used to measure intellectual capital", International Journal of Management Reviews, No. 1, pp. 41-60.

Kaplan, R. and Norton, D. (2004), Strategy Maps: Converting Intangible Assets into Tangible Outcomes, Harvard Business Press, Boston.

Kubo, I. and Saka, A. (2002), "An inquiry into the motivations of knowledge workers in the Japanese financial industry”, Journal of Knowledge Management, Vol. 6 No. 3, pp. 262-271.

Mavridis, D.G. (2004), "The intellectual Capital performance of the Japanese banking sector", Journal of Intellectual Capital, Vol. 5 No. 1, pp. 92-115.

\section{Corresponding author}

A.A. Ousama can be contacted at: osamaanam@gmail.com

For instructions on how to order reprints of this article, please visit our website: 